\title{
Xantelasma Dan Arkus Kornea Juvenilis Sebagai Manifestasi Familial Hypercholesterolemia
}

\author{
Putrigusti Admira $^{1}$, Kemala Sayuti ${ }^{2}$
}

\begin{abstract}
Abstrak
Familial hypercholesterolemia $(\mathrm{FH})$ merupakan kelainan dominan autosomal, disebabkan kelainan pada gen reseptor LDL (low density lipoprotein) di kromosom 19. FH ditandai LDL tinggi, xantelasma, xantoma tuberosum, dan arkus kornea juvenilis. FH diduga pada anak dengan LDL >160mg/dl. Dilaporkan laporan kasus pasien laki-laki 8 tahun dengan manifestasi FH ke mata, yaitu xantelasma dan arkus kornea juvenilis. Pasien konsul dari Bagian Kulit dan Kelamin dengan xantelasma pada palpebra superior mata kiri dan arkus kornea juvenilis sejak 1 tahun yang lalu. Sejak 4 tahun yang lalu, didapatkan benjolan kekuningan pada perut, pinggang, pergelangan tangan, siku, lutut, paha, dan pantat pasien dan makin membesar. Patologi anatomi menggambarkan xanthoma tuberosum. Ditemukan hiperkolesterolemia. Penglihatan normal. Kolesterol total 600mg/dl, LDL 579mg/dl, HDL 33mg/dl, trigliserida 238mg/dl. Terapi awal berupa perubahan gaya hidup, diet, dan observasi segmen posterior bola mata. Arkus kornea juvenilis, xantelasma, dan xantoma tuberosum pada anak dapat diduga $\mathrm{FH}$ dan diperlukan pemeriksaan kolesterol darah.
\end{abstract}

Kata kunci: Hiperkolesterolemia familial, xantoma tuberosum, xantelasma, arkus kornea juvenilis

\begin{abstract}
Familial hypercholesterolemia $(\mathrm{FH})$ is an autosomal dominant disorder caused by defects in the genes coding for the low-density lipoprotein (LDL) receptor at chromosome 19. FH is characterised by high LDL, xanthelasma, tuberous xanthoma, and juvenile corneal arcus. FH should be suspected in children with LDL more than $160 \mathrm{mg} / \mathrm{dl}$. To report a case of 8 years old boy with familial hypercholesterolemia manifests to the eye as xanthelasma and juvenile corneal arcus. A case report. A boy was admitted from dermatologist with xanthelasma at superior eyelid LE and opacity at cornea since 1 year ago. Since 4 years ago, there's lumps on the skin over stomach area, waist, elbows, knees, thighs, and buttocks. The lumps became bigger and multiple. Pathological anatomy revealed tuberous xanthoma. There's hypercholesterolemia. Visual acuity is normal. Total cholesterol $600 \mathrm{mg} / \mathrm{dl}$, LDL $579 \mathrm{mg} / \mathrm{dl}$, HDL $33 \mathrm{mg} / \mathrm{dl}$, and trigliserida $238 \mathrm{mg} / \mathrm{dl}$. Initial treatment for $\mathrm{FH}$ is lifestyle changes, diet modification, and observation for posterior segment of ocular. Existence of juvenile corneal arcus, xanthelasma, and xanthomas tuberosum in children may be suggested for familial hypercholesterolemia, so we need examination of cholesterol.
\end{abstract}

Keywords: familial hypercholesterolemia, tuberous xanthoma, xanthelasma, juvenile corneal arcus

Affiliasi penulis : 1. Program Pendidikan Dokter Spesialis IImu Kesehatan Mata FK Unand Padang, 2. Bagian IImu Kesehatan MATA RSUP DR.M.Djamil Padang

Korespondensi : princess.admira@yahoo.com HP 082331142180

\section{PENDAHULUAN}

Hiperkolesterolemia familial merupakan suatu penyakit autosomal dominan yang disebabkan oleh defek pada gen untuk reseptor low-density lipoprotein (LDL) di kromosom 19. Mutasi gen berupa perubahan dari $\mathrm{C}$ ke $\mathrm{T}$ pada kodon ke33 gen reseptor LDL. Hiperkolesterolemia familial diduga pada pasien dewasa dengan konsentrasi LDL lebih atau sama dengan $190 \mathrm{mg} / \mathrm{dl}$, dan pada pasien anak lebih/sama dengan $160 \mathrm{mg} / \mathrm{dl}$. Pada kasus yang berat, konsentrasi LDL serum dapat melebihi $500 \mathrm{mg} / \mathrm{dl}^{1}{ }^{1}$

Hiperkolesterolemia familial ditemukan pada 1 dari 500 individu di Eropa. Di Polandia, hiperkolesterolemia familial diperkirakan mengenai lebih dari 80.000 individu. Hiperkolesterolemia familial merupakan kelainan genetik yang diketahui dapat menyebabkan $50 \%$ kelainan kardiovaskular lebih awal sebelum usia 50 tahun pada laki-laki dan 30\% kelainan kardiovaskular sebelum usia 60 tahun pada perempuan. Pasien hiperkolesterolemia familial yang tidak diterapi berisiko memiliki penyakit kardiovaskular sebanyak 20 kali lipat bila dibandingkan dengan populasi umum. Kematian karena kelainan kardiovaskular pada pasien hiperkolesterolemia familial pada usia 20-39 tahun 100 kali lipat daripada pasien tanpa hiperkolesterolemia familial. ${ }^{2,3}$

Hiperkolesterolemia familial ditandai dengan adanya peningkatan konsentrasi LDL serum, dan pada pemeriksaan fisik ditemukan adanya xantelasma, xanthoma tuberosum, dan arkus kornea juvenilis. ${ }^{4,5}$

Pada anak dan remaja, xantelasma dapat menjadi sinyal adanya hiperkolesterolemia familial bila disertai oleh arkus kornea juvenilis dan xanthoma tuberosum. Xantelasma diduga sebagai penanda peningkatan risiko aterosklerosis. Adanya xantelasma tidak boleh diremehkan. ${ }^{6,7}$

Selain xantelasma, juga dapat ditemukan arkus kornea juvenilis di kornea pasien. Arkus kornea juvenilis ditemukan pada usia $<50$ tahun. Arkus kornea juvenilis ini merupakan tanda sensitif untuk hiperkolesterolemia familial. ${ }^{8}$

Berikut ini akan dijabarkan mengenai suatu kasus dengan arkus kornea juvenilis ODS dan xantelasma palpebra superior OS pasien laki-laki berusia 8 tahun. Pada pasien ini juga ditemukan adanya xantoma tuberosum, peningkatan LDL serum, dan belum ditemukan tanda-tanda kelainan 
kardiovaskular. Pada keluarga pasien ditemukan riwayat hiperkolesterolemia.

\section{LAPORAN KASUS}

Anak laki-laki berusia 8 tahun, datang bersama pamannya ke Poliklinik Mata RSUP DR. M. Djamil Padang. Pasien dikonsulkan oleh Bagian Kulit dan Kelamin RSUP DR.M. Djamil Padang dengan diagnosa xanthoma tuberosum ec hiperkolesterolemia familial dengan keluhan utama benjolan berwarna kekuningan, tidak gatal, tidak nyeri dan bertambah banyak pada kelopak atas mata kiri sejak 1 tahun yang lalu.

Sejak 1 tahun yang lalu terdapat benjolan berwarna kekuningan pada kelopak atas mata kiri lebih kurang sebesar ujung korek api sebanyak 1 buah. Benjolan tersebut makin lama makin besar dan sekarang berjumlah 2 buah. Nyeri dan gatal tidak ada. Keluhan gangguan penglihatan tidak ada. Warna putih di pinggir bagian hitam kedua mata tidak diketahui sebelumnya.

Awalnya sejak 4 tahun yang lalu muncul 1 benjolan di bagian perut pasien sebesar kepala jarum pentul. Benjolan tersebut membesar dan bertambah banyak. Muncul benjolan yang sama di pinggang, kedua siku, kedua lutut, kedua paha, dan bokong pasien. Beberapa ada yang bergabung-gabung hingga membentuk suatu benjolan besar dengan permukaan yang tidak rata dan perabaan kenyal.

Didapatkan hasil pemeriksaan kolesterol total sebesar 605 mg/dl. Pasien dirujuk ke RS M.Djamil Padang untuk pemeriksaan dan penatalaksanaan. Setelah dilakukan pemeriksaan histopatologi, didapatkan diagnosis xantoma tuberosum.

Keluhan nyeri dada disangkal. Ibu pasien menyatakan bahwa pasien sering mengeluhkan mudah lelah terutama setelah berolahraga dan tampak lesu/tidak bergairah.

Tidak ada anggota keluarga yang menderita keluhan berupa benjolan kekuningan yang menetap, tidak gatal dan tidak nyeri pada kulit seperti yang dialami pasien.

Riwayat hiperkolesterol diketahui pada ibu dan kedua kakak pasien. Ibu pasien berusia 48 tahun dan kakak pasien berusia 22 dan 20 tahun.

Lima tahun yang lalu, ayah pasien meninggal dunia secara mendadak pada usia 47 tahun karena serangan jantung, tidak diketahui riwayat hiperkolesterol dan keluhan sakit jantung. Kedua kakek pasien dari pihak ayah dan ibu diketahui menderita hipertensi, dan meninggal dunia pada usia lebih dari 60 tahun. Riwayat hiperkolesterol tidak diketahui.

Pasien memiliki kebiasaan makan 3x sehari, dengan porsi makan sedang, sumber protein bervariasi antara hewani dan nabati.

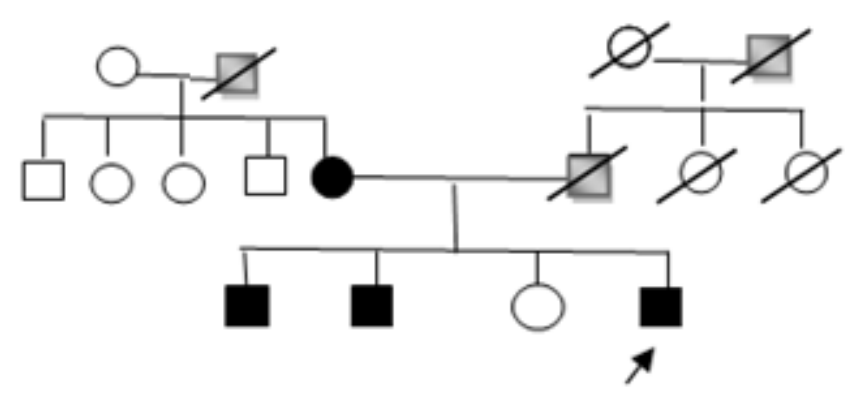

Gambar 1. Silsilah keluarga pasien

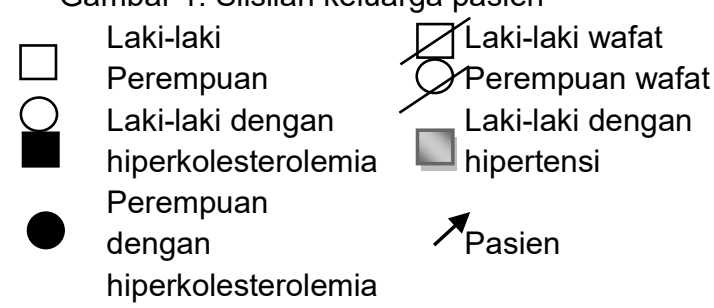

Pasien didapatkan dalam kondisi komposmentis kooperatif, tekanan darah 100/60 $\mathrm{mmHg}$, berat badan $30 \mathrm{~kg}$, dan tinggi badan $124 \mathrm{~cm}$. Pada kulit bagian perut, pinggang, kedua lengan atas, kedua bahu, bokong, dan kedua tungkai pasien didapatkan papul, nodul, serta plak kekuningan dengan permukaan rata, terfiksir, dan perabaan lunak (gambar 2).

Lesi pada kulit pasien tersebut sudah pernah diperiksa secara histopatologis oleh Bagian Patologi Anatomi RSUP DR. M. Djamil Padang. Tampak jaringan kulit dengan epidermis yang menipis, dibawahnya didalam dermis tampak kelompok sel-sel busa, diantaranya terdapat sel-sel histiosit, dan fibroblast, serta banyak serat kolagen dan tampak sedikit sel limposit. Hal ini memberikan kesan suatu xantoma tuberosum.

Dari pemeriksaan oftalmologis didapatkan visus 20/20, arkus kornea juvenilis ODS, dan xantelasma pada palpebra superior OS (gambar 3). Funduskopi dalam batas normal.

Pada Bagian Anak RSUP DR.M.Djamil Padang didapatkan diagnosa hiperkolesterolemia familial. Elektrokardiogram (EKG) dalam batas normal. Dianjurkan untuk terapi manajemen diet dan modifikasi gaya hidup dan dikonsulkan ke Bagian Gizi RSUP DR.M.Djamil Padang. Pasien dianjurkan untuk diet rendah kolesterol dan lemak terbatas dengan 1627 Kkal/hari.

Berdasarkan hasil pemeriksaan laboratorium pasien didapatkan peningkatan pada kolesterol total (600 mg/dl), kolesterol LDL $(579 \mathrm{mg} / \mathrm{dl})$, dan trigliserida $(238 \mathrm{mg} / \mathrm{dl})$, serta penurunan pada kolesterol HDL (33 mg/dl). 

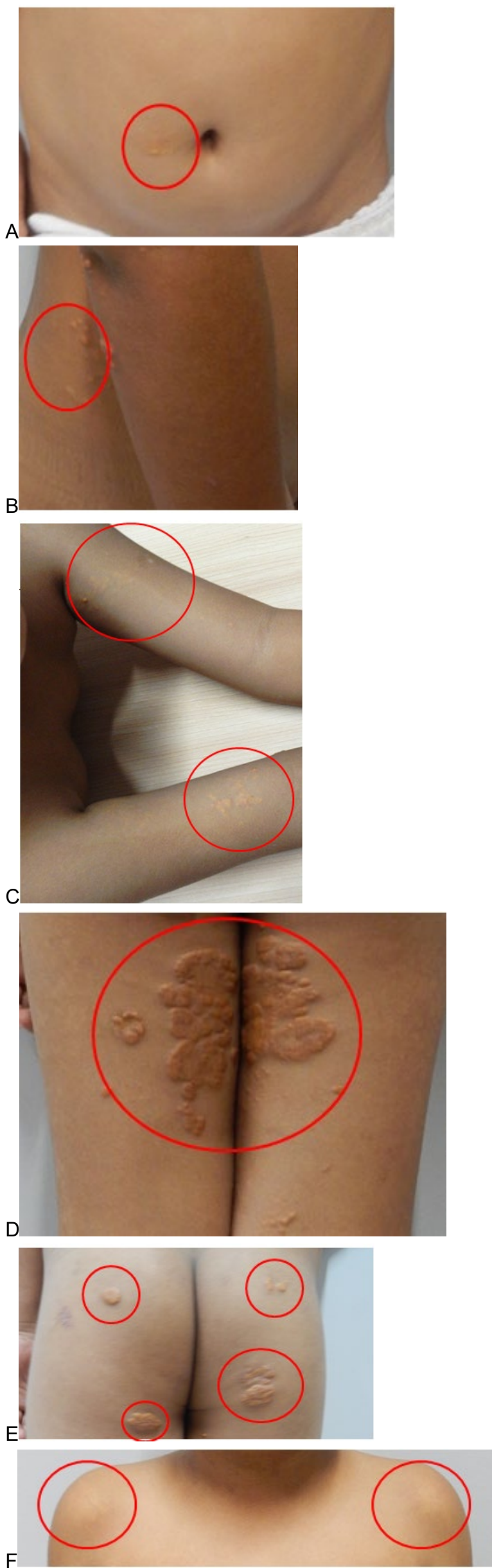

Gambar 2. A) Lesi pada perut, B) pinggang, C) kedua lengan atas, D) kedua tungkai, E) bokong, F) kedua bahu pasien.
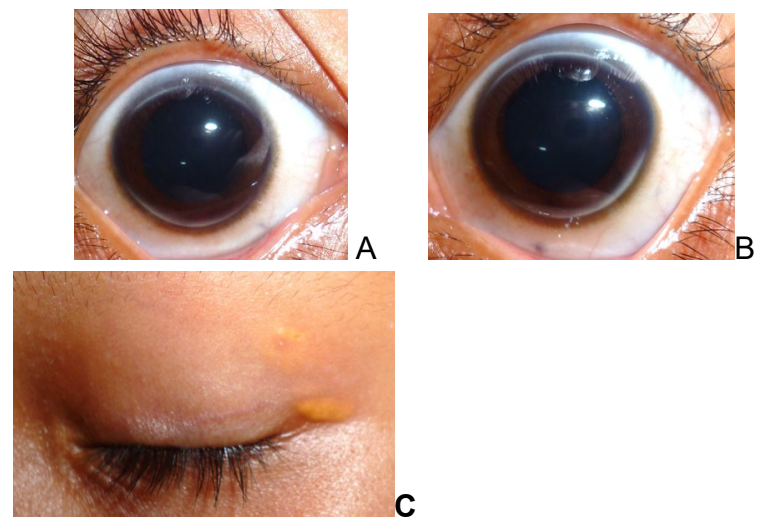

Gambar 3. Arkus kornea juvenilis OD (A), arkus kornea juvenilis $\mathrm{OS}(\mathrm{B})$, dan xantelasma palpebra superior OS (C)

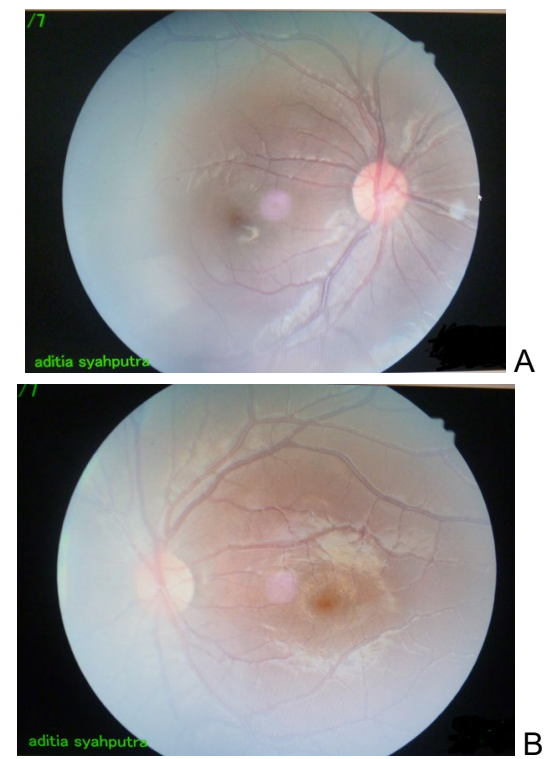

Gambar 4. A) Gambaran funduskopi OD, B) Gambaran funduskopi OS

Pasien didiagnosis xantelasma palpebra superior OS arcus kornea juvenilis ODS et xantoma tuberosum ec hiperkolesterolemia familial. Pasien dilakukan observasi untuk menilai progresivitas xantelasma dan kelainan pada segmen posterior dan kontrol kadar kolesterol pasien

\section{PEMBAHASAN}

Kelainan hiperkolesterolemia ini umumnya bersifat familial. Karena itu skrining terhadap keluarga perlu dilakukan. Diagnosis hiperkolesterolemia familial pada pasien ini ditegakkan dengan ditemukan juga keadaan hiperkolesterolemia pada saudara pasien dan ibu pasien. Ayah pasien meninggal secara mendadak pada usia 47 tahun, akibat kelainan jantung. 
Berdasarkan pemeriksaan oftalmologi didapatkan visus kedua mata normal. Di palpebra superior OS terdapat xantelasma sebanyak 2 buah. Pada kornea ODS terdapat arkus juvenilis. Hal ini sesuai dengan temuan Bansal dan kawan-kawan yang menemukan adanya arkus kornea juvenilis dan xantelasma pada pasien anak laki-laki berusia 12 tahun yang didiagnosa dengan hiperkolesterolemia familial. ${ }^{5}$

Xantelasma dan arkus kornea juvenilis sering dihubungkan dengan kondisi hiperkolesterolemia, yaitu suatu keadaan dengan gangguan kadar kolesterol darah diluar batas normal yang diduga berhubungan dengan proses pembentukan lesi aterosklerosis lebih awal. Secara umum kadar kolesterol pada anak dapat dibagi atas ${ }^{4,9}$ :

1. Acceptable : yakni kadar kolesterol total lebih dari $170 \mathrm{mg} / \mathrm{dl}$ dan atau LDL kolesterol kurang dari $110 \mathrm{mg} / \mathrm{dl}$

2. Borderline : yaitu kadar total kolesterol antara $170-199 \mathrm{mg} / \mathrm{dl}$ dan atau LDL kolesterol 110$129 \mathrm{mg} / \mathrm{dl}$.

3. High : yaitu kadar kolesterol total lebih dari 200mg/dl dan kadar LDL lebih dari $130 \mathrm{mg} / \mathrm{dl}$

Xantelasma merupakan suatu lesi jinak subkutan yang ditandai dengan adanya plak meninggi atau mendatar, berwarna kekuningan yang terdapat di kelopak mata. Xantelasma menandakan adanya deposit histiosit yang mengandung lipid pada lapisan dermis kulit palpebra (sel busa). Sel-sel tersebut cenderung berada di sekitar pembuluh darah. ${ }^{10}$

Mekanisme yang menjelaskan mengenai hubungan antara akumulasi makrofag, peningkatan kolesterol, dan pembentukan sel busa masih belum diketahui. Diduga karena peningkatan lipid plasma teroksidasi menyebabkan akumulasi kolesterol sehingga terjadi akumulasi makrofag dan pembentukan sel busa. ${ }^{11}$

Xantelasma sering menjadi penanda adanya kelainan pada kolesterol serum dan peningkatan risiko aterosklerosis. Xantelasma biasanya muncul pada $50 \%$ pasien hiperlipidemia. Akan tetapi xantelasma juga dapat muncul pada pasien dengan konsentrasi kolesterol serum normal. ${ }^{12}$

Arkus kornea lebih sering ditemukan pada usia tua. Insiden arkus kornea pada usia 50 - 60 tahun yaitu sebanyak $60 \%$, pada usia 70 tahun sebanyak $75 \%$, dan pada usia lebih 80 tahun sebanyak $100 \%$. Arkus kornea yang ditemukan pada usia kurang dari 50 tahun disebut arkus kornea juvenilis. Ditemukannya arkus kornea juvenilis diduga berhubungan dengan risiko pembentukan aterosklerosis. Hal ini sudah dipikirkan sejak tahun 1852 oleh Rudolf Virchow. Zech dan Hoeg melakukan penelitian terhadap 17 pasien dengan hiperkolesterolemia familial, didapatkan bahwa arkus kornea juvenilis yang ditemukan pada pasien kurang dari 50 tahun dapat menjadi indikator adanya hiperlipidemia. Kecurigaan adanya hiperlipidemia ataupun aterosklerosis apabila ditemukan xanthoma dan arkus kornea juvenilis. Pasien dengan arkus kornea juvenilis yang luas cenderung untuk menderita aterosklerosis yang lebih berat. ${ }^{13,14}$

Arkus kornea juvenilis merupakan suatu perubahan degeneratif yang melibatkan deposit lipid ekstraselular di lapisan stroma perifer kornea yang tampak seperti cincin berwarna putih kekuningan dengan lebar sekitar $2 \mathrm{~mm}$. Arkus kornea juvenilis disebut juga dengan istilah embriotokson anterior. Arkus kornea juvenilis umumnya muncul pertama kali di bagian inferior kornea, diikuti dengan bagian superior kornea, kemudian melingkari kornea. Adanya suatu zona yang jernih di antara arkus dengan limbus, yaitu sekitar 0,3 - 1,0 mm (lucid interval). Bagian sentral kornea tidak pernah terlibat. ${ }^{15,16}$

Secara histopatologis, deposit lipid pada awalnya terletak di stroma bagian posterior dan kemudian berlanjut ke stroma bagian anterior. Di bagian pertengahan lapisan stroma kornea, kepadatan deposit lipid ini berkurang sehingga memberikan gambaran seperti jam pasir. Pada kasus yang berat, deposit lipid dapat ditemukan di seluruh stroma, termasuk membran Bowman dan membran Descemet. ${ }^{15,16}$

Deposit lipid tersebut terdiri dari kolesterol ekstraselular, kolesterol ester, fosfolipid, dan trigliserida. Deposit lipid ini, terutama LDL berasal dari vaskular, keluar dari kapiler limbus dan masuk ke dalam kornea. Pada endotel pembuluh darah terdapat tight junction yang berfungsi sebagai barrier tetapi dengan adanya peningkatan LDL darah, barrier ini tidak dapat berfungsi. Penelitian menunjukkan bahwa deposit lipid di kornea ini mirip dengan deposit lipid pada pembuluh darah aterosklerosis, kecuali tanpa adanya sel busa. ${ }^{15,16}$

Arkus kornea juvenilis terbentuk di area dengan permeabilitas vaskular yang meningkat. Pada area yang lebih hangat di kornea, terjadi peningkatan permeabilitas vaskular sehingga timbul deposit lipid. Bagian inferior dan superior kornea lebih hangat daripada bagian sentral kornea maka arkus kornea juvenilis cenderung terbentuk di perifer. Adanya lucid interval diduga disebabkan karena kemampuan pembuluh darah limbus untuk mengabsorbsi lipid pada area ini sebelum mengendap di kornea. ${ }^{15}$

Pada segmen posterior pasien ini tidak ditemukan adanya kelainan, walaupun dari kepustakaan didapatkan bahwa hiperkolesterolemia familial dapat menyebabkan munculnya kelainan pada retina. Kebocoran lipoprotein di retina dapat bermanifes sebagai hard exudates. LDL yang teroksidasi dapat menyebabkan diproduksinya sitokin sehingga timbul reaksi inflamasi. Salam melaporkan adanya kelainan pada retina pasien hiperkolesterolemia familial yang berumur 9 tahun berupa hard exudates tanpa gangguan pada pembuluh darah retina. Pasien tersebut tidak mengalami gangguan pada tajam penglihatan. ${ }^{17}$ 
Pada kulit bagian perut, pinggang, kedua lengan atas, kedua bahu, bokong, dan kedua tungkai pasien didapatkan papul, nodul, serta plak kekuningan dengan permukaan rata, terfiksir, dan perabaan lunak yang didiagnosis sebagai xantoma tuberosum. Hal ini sesuai dengan kepustakaan bahwa pada hiperkolesterolemia familial juga dapat ditemukan adanya xantoma tuberosum. ${ }^{4}$

Berdasarkan hasil pemeriksaan Bagian Anak RSUP DR.M.Djamil Padang didapatkan diagnosa hiperkolesterolemia familial dengan berat badan berlebih, tanpa peningkatan tekanan darah, dan hasil pemeriksaan elektrokardiogram (EKG) dalam batas normal. Pemeriksaan terhadap jantung ini perlu dilakukan karena risiko gangguan kardiovaskular pada pasien dengan hiperkolesterolemia familial menjadi 20 kali lipat lebih tinggi daripada orang normal. ${ }^{18}$

Berdasarkan hasil pemeriksaan laboratorium didapatkan peningkatan pada kolesterol LDL sekitar $579 \mathrm{mg} / \mathrm{dl}$. Hal ini sesuai dengan kepustakaan bahwa hiperkolesterolemia familial diduga terjadi pada pasien anak yang memiliki kolesterol LDL lebih/sama dengan $160 \mathrm{mg} / \mathrm{dl}^{2}{ }^{2} \mathrm{Hal}$ ini sesuai dengan yang didapatkan oleh Singh dan Simalti. Mereka melaporkan suatu laporan kasus anak laki-laki berumur 7 tahun dengan diagnosis xantoma tuberosum yang memiliki kolesterol LDL sekitar $640 \mathrm{mg} / \mathrm{dl}^{6}$

Manajemen awal pasien dengan hiperkolesterolemia familial adalah dengan perubahan gaya hidup dan pengaturan diet. Pasien dianjurkan untuk melakukan aktivitas fisik minimal 30 menit tiap hari dan dapat ditingkatkan menjadi 60 menit per hari. Aktivitas fisik dapat mengurangi produksi LDL, meningkatkan produksi $\mathrm{HDL}$, serta menghambat proses katabolisme HDL. Selain itu, pasien juga sebaiknya mengkonsumsi makanan dengan aturan total lemak sebesar 25 - 30\% dari total energi, lemak jenuh kurang dari $7 \%$ dari total energi, makanan berkolesterol kurang dari $200 \mathrm{mg} / \mathrm{hari}$, dan serat sekitar 2 gram/hari. Konsumsi lemak jenuh dapat diganti dengan konsumsi lemak tak jenuh dari sayursayuran dan ikan. Hal ini dapat menurunkan LDL sekitar $15 \% .^{19}$ Pada pasien ini telah dilakukan konseling gizi, dan kepada pasien diberikan diet rendah kolesterol dengan 1627 kalori per hari.

Perubahan gaya hidup dan pengaturan diet pada pasien hiperkolesterolemia familial sering tidak berhasil dalam menurunkan kadar LDL. Bila kadar LDL tetap tinggi setelah 3 bulan, sebaiknya dipikirkan pemberian terapi obat untuk menurunkan kolesterol. Saat ini, belum ada pedoman pasti untuk terapi pasien hiperkolesterolemia familial pada anak. Terapi obat terutama dianjurkan bila ada riwayat keluarga dengan hiperkolesterolemia dan penyakit jantung koroner pada dekade ketiga dan keempat kehidupan, terutama orangtua pasien. ${ }^{19}$

Terapi modifikasi gaya hidup dengan diet rendah kolesterol dan lemak terbatas pada pasien diharapkan dapat memberi hasil berupa penurunan kadar kolesterol. Untuk modifikasi gaya hidup, pembatasan makanan yang mengandung lemak tinggi seperti daging sapi, babi, berbagai jenis organ dalam binatang, dan kuning telur. Meningkatkan konsumsi sayuran segar, buah-buahan, kacang-kacangan dan makanan yang mengandung serat akan membantu mengeluarkan kolesterol. Penggantian total protein hewani dengan protein nabati dari kacang kedelai telah dilaporkan dapat mengurangi kadar kolesterol total plasma dan kolesterol LDL. Protein kedelai dapat menurunkan kadar kolesterol total sebanyak 20,8\% dan LDL $25,8 \%$ pada pasien hiperkolesterolemia familial. $^{2,8}$

Pilihan terapi untuk lesi xantelasma pada pasien ini yaitu observasi. Xantelasma dapat hilang total setelah beberapa tahun bila kolesterol serum dapat dipertahankan dalam batas normal. Eksisi dilakukan pada lesi yang luas atau mengganggu secara kosmetik. Xantelasma dengan ketinggian plak melebihi atau sama dengan $5 \mathrm{~mm}$, tindakan eksisi dapat memberikan hasil yang memuaskan. Pemberian asam trikloroasetik dan asam biklorasetik juga dapat efektif. Pasien xantelasma yang diterapi tiap bulan sebanyak lima kali dengan pemberian topikal asam trikloroasetik 33\%. Didapatkan hasil berupa penurunan ketinggian plak dan penurunan ukuran xantelasma. Terapi xantelasma dengan asam bikloroasetik topikal $100 \%$ dapat memberikan hasil kosmetik yang baik dan memuaskan pasien. ${ }^{20,21}$

\section{SIMPULAN}

Diagnosis familial hypercholesterolemia pada pasien laki-laki umur 8 tahun ini ditegakkan dengan hasil laboratorium kolesterol LDL yang tinggi, ditemukannya xantelasma, arkus kornea juvenilis, dan xantoma tuberosum. Didukung oleh adanya riwayat hiperkolesterolemia pada ibu dan kakak pasien serta riwayat hipertensi pada ayah pasien.

Adanya arkus kornea juvenilis, xantelasma, dan xantoma tuberosum pada pasien usia muda dapat menjadi penanda terhadap adanya gangguan berupa hiperkolesterolemia yang mengarah kepada hiperkolesterolemia familial sehingga bila ditemukan beberapa kondisi tersebut, perlu pemeriksaan lebih lanjut terhadap kondisi sistemik pasien untuk membantu dalam menegakkan diagnosis.

\section{DAFTAR PUSTAKA}

1. Meng X, Lin J, Gao X, Guo J, Xin C, Wang J. Corneal Arcus And Xanthomas In Familial Hypercholesterolemia : First Report From China. Indian Journal Of Ophthalmology 2013;61(12): pp.770-771.

2. Mysliwiec M, Walczak M, Malecka-Tendera E, Dobrzanska A, Cybulska B, Filipiak K, dkk.

Management Of Familial Hypercholesterolemia In Children And Adolescents. Journal Of Clinical

Lipidology 2014;8: pp.173-180.

3. Knowles JW, O'Brien EC, Greendale K, Wilemon K, Genest J, Sperling LS. Reducing The Burden Of Disease And Death From Familial 
Hypercholesterolemia. American Heart Journal 2014;12: pp.807-809.

4. Zak A, Zeman M, Slaby A, Vecka M. Xanthomas : Clinical And Pathophysiological Relations. Biomed Pap Med Fac Univ Palacky Olomous Czech Repub 2014; 158(2): pp.181-188.

5. Bansal M, Manchanda K, Pandey SS. Familial Hyperlipoproteinemia Presenting With Different Types Of Xanthomas. Indian Journal Of Paediatric Dermatology 2014;15: pp.39-41.

6. Singh RK, Simalti AK. Tuberous Xanthoma. Indian Pediatrics 2009;46(17): p.727.

7. Pietroleonardo L \& Ruzicka T. Skin Manifestations In Familial Hypercholesterolemia. Acta Dermatoven APA 2009;18(4): pp.183-6.

8. Thappa DM, Karthikeyan K. Arcus Juvenilis And Xanthelasma. Indian Pediatrics 2003;40: pp.574575

9. Al-rasadi $\mathrm{K}, \mathrm{Al}$-waili $\mathrm{K}, \mathrm{Al}$-sabti HA, Al-hinai A, Alhasmi $\mathrm{K}, \mathrm{Al}$-zakwani I. Criteria for diagnosis of familial hypercholesterolemia: A comprehensive analysis of the different guidelines, appraising their suitability in the Omani Arab population. Oman Medical Journal 2014;2: pp.85-91.

10. Shields JA, Shields CL. Eyelid, Conjunctival, And Orbital Tumors 2nd Edition, 2008. Philadelphia : Lippincott Williams \& Wilkins.p. 174

11. Akhyani $M$, Daneshpazhooh $M$, Jafari AK, Naraghi ZS, Farahani F, Toosi S. Xanthelasma After Treatment With Trichloroacetic Acid. Dermatology Online Journal, 2012;2: p.12.

12. Lee HY, Jin US, Minn KW, Park YO. Outcomes Of Surgical Management Of Xanthelasma Palpebrarum. Arch Plastic Surgery, 2013;40: pp.380-386.

13. Urbano FL. Ocular Signs Of Hyperlipidemia. Hospital Physician 2001;12: pp.51-53.

14. Zech LA, Hoeg JM. Correlating Corneal Arcus With Atherosclerosis In Familial Hypercholesterolemia. Lipids In Health And Disease 2008;7: p.7.

15. Waheed NK, Azar N. Congenital Abnormalities And Metabolic Diseases Affecting The Conjunctiva And Cornea. Dalam : Smolin And Thoft's : The Cornea 4th Edition, 2005. Philadelphia : Lippincott Williams \& Wilkins.p.716.

16. Chang RI, Ching SST. Corneal And Conjunctival Degenerations. Dalam : Krachmer JH, Mannis MJ, Holland EJ (eds.) Fundamentals, Diagnosis And Management Cornea 2nd Edition, 2005. Philadelphia : Elsevier Mosby.pp.987-988.

17. Salam A, Palimar P, Davis A. Statin sensitive Lipid-retinopathy In Familial Hypercholesterolemia. Journal Of Clinical Ophthalmology And Research 2013;1(3): pp.155156.

18. Foody JM. Familial Hypercholesterolemia : An Under-recognized But Significant Concern In
Cardiology Practice. Clinical Cardiology 2014;37(2): pp.119-125.

19. Goldberg AC, Hopskins PN, Toth PP, Ballantyne CM, Rader DJ, Robinson JG. Familial hypercholesterolemia : screening, diagnosis and management of pediatric and adult patients. Journal of Clinical Lipidology 2011;5(3): pp.133140.

20. Shields CL, Mashayekhi A, Shields JA, Racciato P. Disappearance Of Eyelid Xanthelasma Following Oral Simvastatin British Journal Ophthalmology 2005; 89(5): pp.639-640.

21. Haygood LJ, Bennett JD, Brodell RT. Treatment Of Xanthelasma Palpebrarum With Bichloroacetic Acid. Dermatologic Surgery 1998;24(9): pp.10271031. 